\title{
In vitro immune responses of porcine alveolar macrophages reflect host immune responses against porcine reproductive and respiratory syndrome viruses
}

Nadeem Shabir ${ }^{1,2 \dagger}$, Amina Khatun ${ }^{1 \dagger}$, Salik Nazki ${ }^{1}$, Suna Gu³, Sang-Myoung Lee ${ }^{3}$, Tai-Young Hur ${ }^{4}$, Myoun-Sik Yang ${ }^{1}$, Bumseok Kim ${ }^{1}$ and Won-II Kim ${ }^{1 *}$ (D)

\begin{abstract}
Background: Currently, an in vitro immunogenicity screening system for the immunological assessment of potential porcine reproductive and respiratory syndrome virus (PRRSV) vaccine candidates is highly desired. Thus, in the present study, two genetically divergent PRRSVs were characterized in vitro and in vivo to identify an in vitro system and immunological markers that predict the host immune response. Porcine alveolar macrophages (PAMs) and peripheral blood mononuclear cells (PBMCs) collected from PRRSV-negative pigs were used for in vitro immunological evaluation, and the response of these cells to VR2332C or JA142C were compared with those elicited in pigs challenged with the same viruses.

Results: Compared with VR2332C or mock infection, JA142C induced increased levels of type I interferons and proinflammatory cytokines (TNF-a, IL-1a/ $\beta, I L-6, I L-8$, and IL-12) in PAMs, and these elevated levels were comparable to the cytokine induction observed in PRRSV-challenged pigs. Furthermore, significantly greater numbers of activated CD4 ${ }^{+} \mathrm{T}$ cells, type I helper T cells, cytotoxic T cells and total IFN- $\gamma^{+}$cells were observed in JA142c-challenged pigs than in VR2332C- or mock-challenged pigs.
\end{abstract}

Conclusions: Based on these results, the innate immune response patterns (particularly IFN-a, TNF- $a$ and IL-12) to specific PRRSV strains in PAMs might reflect those elicited by the same viruses in pigs.

Keywords: PRRSV, Immune response, Alveolar macrophages, Peripheral blood mononuclear cells, Flow cytometry

\section{Background}

Porcine reproductive and respiratory syndrome virus (PRRSV), a positive-sense RNA virus belonging to the family Arteriviridae of the order Nidovirales, exerts a significant economic impact on the swine industry worldwide [1-3], with an estimated annual loss of at least $\$ 664$ million in the USA alone [4]. PRRSV possesses a $15-\mathrm{kb}$ polycistronic genome containing two large open reading frames (ORFs 1a and 1b) that encode non-structural proteins (NSPs) and eight structural protein-encoding ORFs (2a, 2b, 3, 4, 5a, 5, 6 and 7) [5, 6]. PRRSV is broadly

\footnotetext{
* Correspondence: kwi0621@jbnu.ac.kr

†Nadeem Shabir and Amina Khatun contributed equally to this work.

${ }^{1}$ College of Veterinary Medicine, Chonbuk National University, 79 Gobong-ro, Iksan, Jeonbuk, Korea

Full list of author information is available at the end of the article
}

classified into two divergent genotypes, European (Type I) and North American (Type II), with Type II PRRSVs further sub-divided into at least nine different genetic lineages with inter-lineage genetic distances varying from 11 to $18 \%[7,8]$. The high genetic variability that exists between different PRRSV strains has resulted in increased antigenic and immunological diversity $[9,10]$. This diversity among PRRSVs not only hinders our understanding of PRRSV-induced immunity in pigs but also poses a serious hurdle for the selection of immunogenic strains for vaccine development [11]. Moreover, due to the lack of immunological classification of divergent PRRSV strains and reliable parameters for predicting vaccine protection, the immunogenicity and protective efficacy of PRRSV vaccine

(c) The Author(s). 2018 Open Access This article is distributed under the terms of the Creative Commons Attribution 4.0 International License (http://creativecommons.org/licenses/by/4.0/), which permits unrestricted use, distribution, and reproduction in any medium, provided you give appropriate credit to the original author(s) and the source, provide a link to the Creative Commons license, and indicate if changes were made. The Creative Commons Public Domain Dedication waiver (http://creativecommons.org/publicdomain/zero/1.0/) applies to the data made available in this article, unless otherwise stated. 
candidates can be only evaluated through challenge experiments in pigs [12].

The immune responses elicited by PRRSV in vitro and in vivo have been well-studied, but researchers have not reached a consensus on immune response patterns. PRRSV reportedly up-regulates IL-10 [13-15] and induces insignificant amounts of or inhibits the expression of type I interferons (IFNs) and TNF- $\alpha$ in vitro and/or in vivo [16-20]. However, some in vitro and in vivo studies have also demonstrated that the induction of these cytokines is strain dependent [21-24]. According to the majority of studies, PRRSVs induce IL-8 $[25,26]$, and the in vitro/ex vivo induction of IL- 6 by PRRSV has also been reported [27-29].

Our current understanding of cell-mediated immune responses to PRRSV is unclear. IFN- $\gamma$ has been used as a marker of Th1 polarization during PRRSV infection $[30,31]$. Cytotoxic T cell activity against PRRSV-infected macrophages was only induced at 49 days post-infection [32], and weak PRRSV-specific cytotoxic T cell responses $\left(\mathrm{CD} 8^{+} \mathrm{IFN}-\gamma^{+}\right)$were reported in another study [33]. Furthermore, PRRSV infection increases the number of TGF- $\beta$ producing regulatory $\mathrm{T}$ cells $\left(\mathrm{T}_{\text {Regs }}\right)$ [34]. In addition, monocyte-derived dendritic cells (MoDCs) infected with PRRSV do not increase the frequency and proliferation of $\mathrm{T}_{\text {Regs }}$ in an in vitro co-culture system [35]. The negligible innate immune responses induced by PRRSV may severely affect adaptive immunity; along with other irregular adaptive immune processes, this impaired response leads to overall immune inefficiency and co-infections [36]. Therefore, it is important to understand early innate immunity events to gain insight into the immune response to PRRSV infection [37, 38].

The role of neutralizing antibodies (NAbs) during PRRSV infection is not completely understood [39]. PRRSV NAbs usually appear during the third or fourth week post-infection [36], and an NAb titre of 1:8 is sufficient to block viremia in PRRSV-infected pigs. However, NAb induction may be dependent on the strain of PRRSV [40, 41].

Given the strain-dependent elicitation of innate, cell-mediated and humoral immune responses by PRRSV, multiple virus strains should be investigated to gain a better understanding of PRRSV immunobiology [9]. Thus, there is a need to select an in vitro system to immunologically classify diverse PRRSVs and to predict the protection and immune responses induced by vaccine candidates. The majority of previous studies examining PRRSV-induced immune responses have used a single PRRSV strain that was tested either in vitro or in vivo but rarely both. These studies also failed to take into account the effects of PRRSV strain diversity, immune evaluation systems, or both when drawing general conclusions regarding PRRSV immunobiology. To fill in these gaps, the current study focused on two important goals: i) in vitro and in vivo characterization of the immune responses elicited by two divergent Type II PRRSV strains, and ii) identification of a feasible in vitro model or specific immunological markers to predict the in vivo immune responses induced by a PRRSV strain.

\section{Results}

PRRSVs replicated at similar levels in PAMs and pigs

A multi-step growth curve for PRRSV replication in PAMs was constructed by measuring viral titres in cell lysates at $6,12,24,36$ and $48 \mathrm{~h}$ post-infection (hpi). Slightly higher levels of viral replication were observed for JA142c than for VR2332c in PAMs (Fig. 1a) and in pigs (Fig. 1b), but these differences were not statistically significant. Neither strain produced viral titres at $6 \mathrm{hpi}$ in PAMs, but JA142c and VR2332c exhibited titres of $10^{2.5}$ and $10^{1.5} \mathrm{TCID}_{50} / \mathrm{mL}$ at $12 \mathrm{hpi}$, gradually increasing to $10^{3.75}$ and $10^{3.5} \mathrm{TCID}_{50} / \mathrm{mL}$, respectively, at $48 \mathrm{hpi}$. In a pig challenge model, the animals were tested for viremia at $0,3,7,14,21$ and $28 \mathrm{dpc}$. The mean levels of viremia in a

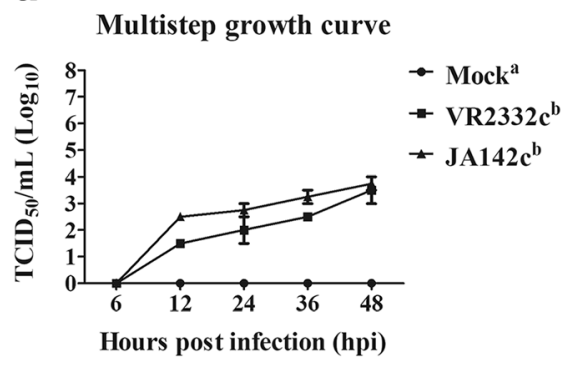

b

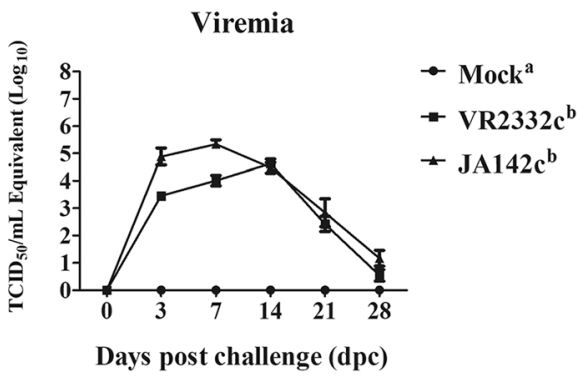

Fig. 1 PRRSV replication in PAMs and pigs. a Multi-step growth curve of PRRSVs in PAMs $(n=6)$ at 6, 12, 24, 36 and 48 hpi, as determined by titration using MARC-145 cells. b Viral loads in pig sera $(n=5)$ at $0,3,7,14,21$ and $28 \mathrm{dpc}$, as determined by a quantitative real-time PCR for PRRSV. The bars represent the means, and the error bars represent the standard errors of the mean (SEM). Bars showing different letters represent values that differ significantly from each other $(p<0.05)$ 
pigs challenged with VR2332c or JA142c peaked at 14 and $7 \mathrm{dpc}$, with values of $10^{4.6}$ and $10^{5.3} \mathrm{TCID}_{50} / \mathrm{mL}$, and then gradually decreased to $10^{0.5}$ and $10^{1.1} \log _{10} \mathrm{TCID}_{50} / \mathrm{mL}$, respectively. Overall, JA142c and VR2332c demonstrated similar levels of replication in pigs and PAMs.

\section{JA142c exhibited increased cytokine transcript and protein levels in PAM and PBMC cultures}

Cytokine levels in PAMs, PBMCs and cell supernatants or lysates were evaluated by real-time PCR and/or ELISA. Compared to those of mock infection or VR2332c, JA142c and poly I:C induced significantly increased transcript levels of IFN- $\beta$ and pro-inflammatory cytokines (IL-1 $\alpha$, IL-1 $\beta$, IL-6, IL-8, IL-12, and TNF- $\alpha$ ) at either two or all three time points assayed (12, 24 and 36 hpi) (Fig. 2a). Furthermore, significantly higher TNF- $\alpha$ and IFN- $\alpha$ levels were observed in the cell lysates of JA142c-infected PAMs than in the cell lysates of the mock- or VR2332c-infected groups for at least two out of three time points (Fig. 2b). However, there was no significant difference in IL-12 protein expression in PAM lysates between groups. In naïve PBMCs, JA142c induced significantly higher IL- $1 \alpha$, IL- $1 \beta$ and TNF- $\alpha$ mRNA transcript levels at 12 and/or $36 \mathrm{hpi}$ (Fig. 3a). Further, TNF- $\alpha$ protein expression in JA142c-stimulated naive PBMCs was significantly higher at 12 and 36 hpi (Fig. 3b).

\section{JA142c induced higher levels of type I IFNs and pro- inflammatory cytokines in pigs}

Regarding cytokine mRNA transcript levels in PBMCs collected from virus-challenged pigs, JA142c-infected pigs had significantly higher transcript levels of IFN- $\beta$ and IL- 6 that pigs subjected to other treatments at 7 or $14 \mathrm{dpc}$. The transcript levels of IL-8, IL-12 and IFN- $\gamma$ at 7,21 or $28 \mathrm{dpc}$ were higher in JA142c-infected pigs than in the other groups, but these differences were not statistically significant (Fig. 4). Serum cytokines in pigs were evaluated by performing ELISA (Fig. 5).

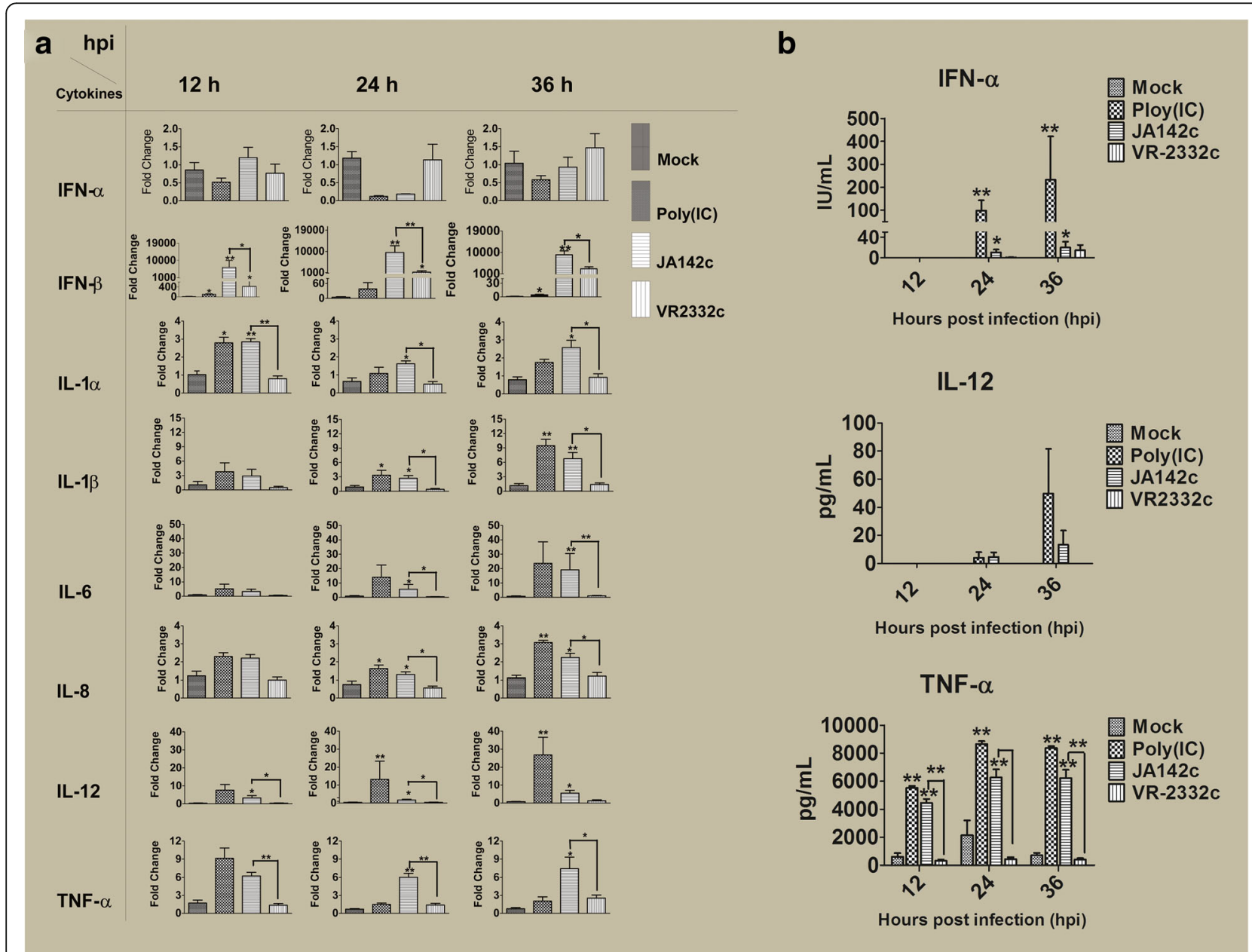

Fig. 2 Cytokine expression in PAM cultures. a mRNA and $\mathbf{b}$ protein expression of cytokines in PAMs and supernatants $(n=6)$, as determined by real-time PCR and ELISA, respectively, at 12,24 and 36 hpi. Asterisks indicate significant differences in the cytokine expression induced by each virus or stimulant compared with mock treatment or significant differences between JA142C and VR2332C (* indicates $p \leq 0.05,{ }^{* *}$ indicates $p \leq 0.01$ ) 


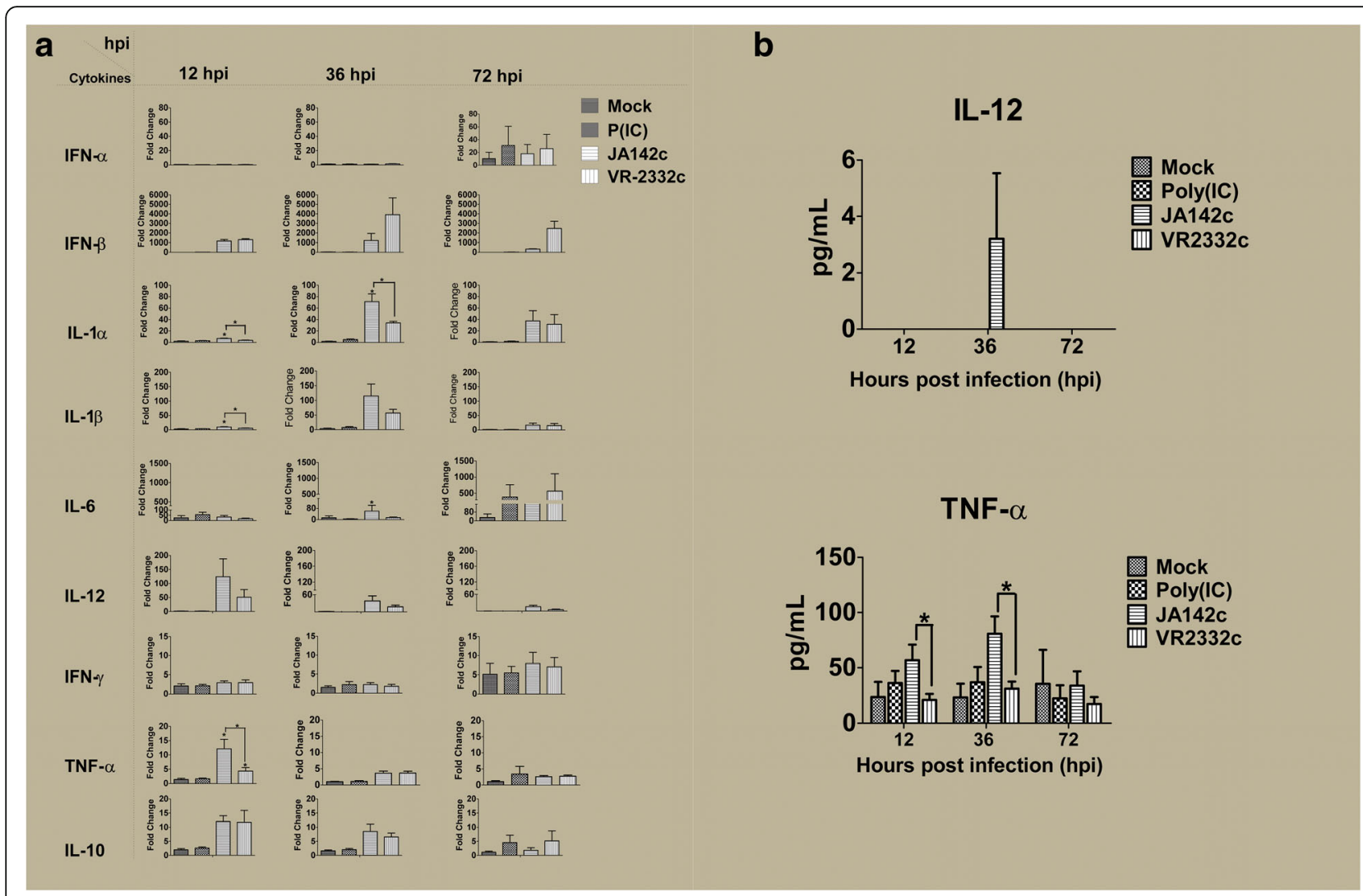

Fig. 3 Cytokine expression in PBMC cultures. a mRNA and $\mathbf{b}$ protein expression of cytokines in PBMCs and supernatants $(n=6)$, as determined by real-time PCR and ELISA, respectively, at 12, 36 and 72 hpi. Asterisks indicate significant differences in cytokine expression induced by each virus or stimulant compared with mock treatment or significant differences between JA142C and VR2332C (* indicates $p \leq 0.05$, ${ }^{* *}$ indicates $p \leq 0.01$ )

Although a significantly stronger induction of serum IFN- $\alpha$ was observed in VR2332c-infected pigs than in mock-infected pigs at $3 \mathrm{dpc}$, JA142c induced serum IFN- $\alpha$ levels that were significantly and consistently higher than those in either the VR2332c- or mock-infected groups until $14 \mathrm{dpc}$. Moreover, serum pro-inflammatory cytokine induction was enhanced. Specifically, TNF- $\alpha$ and IL-12 levels were significantly higher in JA142c-infected pigs from 7 to $14 \mathrm{dpc}$ than in VR2332c- and mock-infected pigs; however, comparable levels of these cytokines were found in JA142c- and VR2332c-infected pigs at 21 and 28 dpi. JA142c also induced significantly higher serum levels of IL-4 at $21 \mathrm{dpc}$ than did VR2332c.

A type I IFN bioassay using sera from virus-challenged pigs at $3 \mathrm{dpc}$ revealed significantly higher antiviral activity in JA142c-challenged pigs than in mock- and VR2332c-challenged pigs (Fig. 6).

\section{JA142c induced an enhanced cell-mediated immune response in pigs}

As shown in Fig. 7, JA142c induced a significantly higher proportion of activated $\mathrm{CD} 4^{+} \mathrm{T}$ cells $\left(\mathrm{CD} 4^{+} \mathrm{CD} 25^{+} \mathrm{FoxP}^{-}\right)$ at 21 and $28 \mathrm{dpc}$ than did mock or VR2332c challenge in pigs. In addition, significantly higher numbers of type I helper $\mathrm{T}$ cells $\left(\mathrm{CD} 4^{+} \mathrm{IFN}-\gamma^{+}\right)$and cytotoxic $\mathrm{T}$ cells $\left(\mathrm{CD}^{+}{ }^{+} \mathrm{IFN}-\gamma^{+}\right)$among PBMCs were observed in JA142c-infected pigs at 14 and $21 \mathrm{dpc}$ than in mock- or VR2332c-challenged pigs. Total IFN $-\gamma^{+}$lymphocytes in the JA142c-infected group were significantly higher at 14 and 21 dpc. Furthermore, regulatory $\mathrm{T}$ cell $\left(\mathrm{CD} 4^{+} \mathrm{CD} 25^{+} \mathrm{FoxP}^{+}\right)$numbers were significantly lower in JA142c-infected pigs at $3 \mathrm{dpc}$ and in JA142c- and VR2332c-infected pigs at $14 \mathrm{dpc}$ than in the mock-infected group, although these levels gradually increased by $28 \mathrm{dpc}$ in both groups.

\section{Induction of PRRSV-specific antibodies after challenge}

The PRRSV-specific antibody (IgG) response was measured by performing a nucleocapsid $(\mathrm{N})$ protein-based ELISA for the two virus-challenged groups. The pigs seroconverted after 2 weeks of exposure to PRRSV and remained seropositive until the end of the study (Fig. 8a). The negative control group remained seronegative until the end of the study. No significant differences in the 


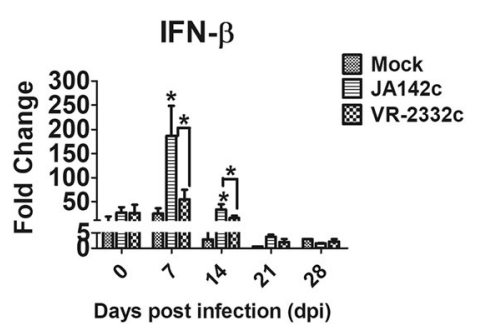

IL-6

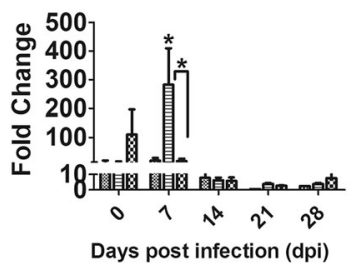

IL-12

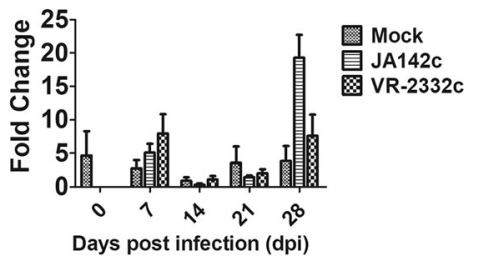

IL-1 $\beta$

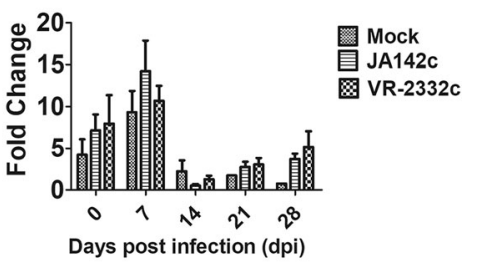

IL-8

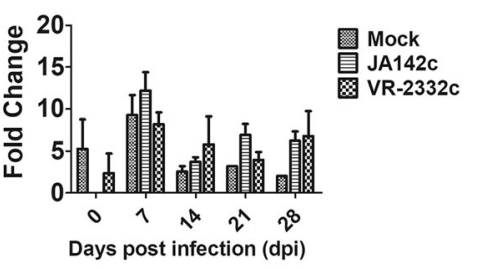

IFN- $\gamma$

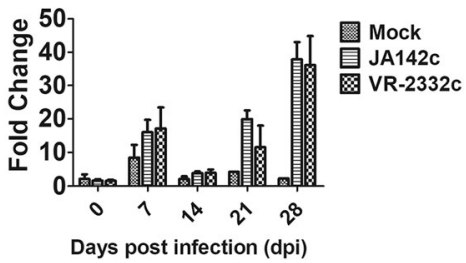

Fig. 4 mRNA transcription of cytokines in PBMCs collected from pigs infected with the VR2332C and JA142C PRRSV strains at 0, 7, 14, 21 and 28 $\mathrm{dpc}$. Analysis of mRNA transcription in PBMCs $(n=5)$ collected from infected and control pigs using real-time PCR. Asterisks indicate significant differences in cytokine expression induced by each virus compared with mock treatment or significant differences between JA142C and VR2332C ( ${ }^{*}$ indicates $p \leq 0.05$ )

IgG response were detected between the JA142c- and VR2332c-challenged groups.

NAb levels in the collected serum samples were determined using an FFN assay. At $28 \mathrm{dpc}$, only homologous NAbs were induced, and no significant cross-NAbs were induced by either VR2332c or JA142c (Fig. 8b and c).

\section{Lung pathology and viral load}

JA142c-infected pigs $\left(3.1 \pm 0.67 \mathrm{TCID}_{50} / \mathrm{mL}\right)$ had higher residual viral loads in the lung than VR2332c-infected pigs $\left(1.662 \pm 0.22 \mathrm{TCID}_{50} / \mathrm{mL}\right)$; however, this difference was not statistically significant (Fig. 9a). Furthermore, there were no significant differences in gross or microscopic lung lesion scores among the groups challenged with JA142c or VR2332c (Fig. 9b \& c).

\section{Discussion}

It has been demonstrated that type I IFNs (IFN- $\alpha$ and IFN- $\beta$ ) play an important role in the induction of innate and adaptive immunity during PRRSV infection [42, 43]. In the current study, JA142c induced higher IFN- $\alpha$ production in PAMs than did VR2332c. This differential IFN- $\alpha$ induction in PAMs is consistent with the results of previous study that demonstrated variable IFN- $\alpha$ production in response to different Type II PRRSV isolates [22]. Moreover, compared with VR2332c, JA142c induced the production of significantly increased serum IFN- $\alpha$ levels in pigs from 3 to $14 \mathrm{dpc}$, which is in partial agreement with a previous study demonstrating lower levels of serum IFN- $\alpha$ in VR2332c-infected pigs [44]. In addition, JA142c induced significantly higher IFN- $\beta$ transcription than did VR2332c in naïve PAMs, similar to the results of previous studies describing high IFN- $\beta$ transcription in PAMs following infection by several PRRSV strains [45-47]. Because PRRSV could modulate and block type I IFN induction [39], these results indicated that VR2332c might exert enhanced inhibitory effects on type I IFN production in PAMs as well as in pigs. Furthermore, in the present study, JA142c induced significantly higher TNF- $\alpha$ production in PAMs and pigs than did VR2332c. This observation is consistent with previous studies that reported various levels of TNF- $\alpha$ induction in PRRSV-infected PAMs, PBMCs, or pigs $[9,19,20,25,44,48-50]$. TNF- $\alpha$ is another major pro-inflammatory cytokine that promotes the antiviral state in uninfected neighbouring cells and recruits lymphocytes to sites of infection [48]. Similarly, significantly higher mRNA transcription of other pro-inflammatory cytokines (IL-1 $\alpha / \beta$, IL-6, IL-8 and IL-12) 
a

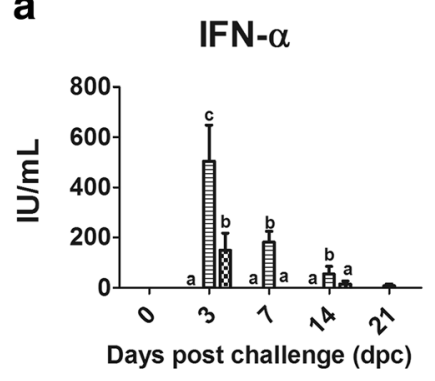

C

IL-12

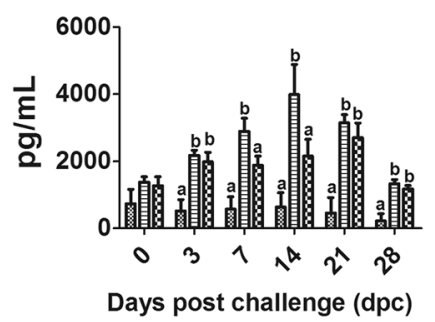

e

\section{IL-4}

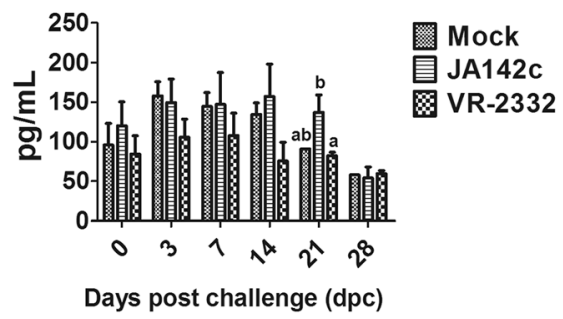

b

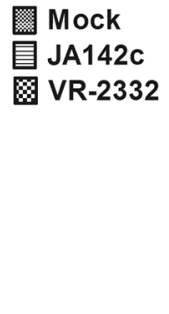

d

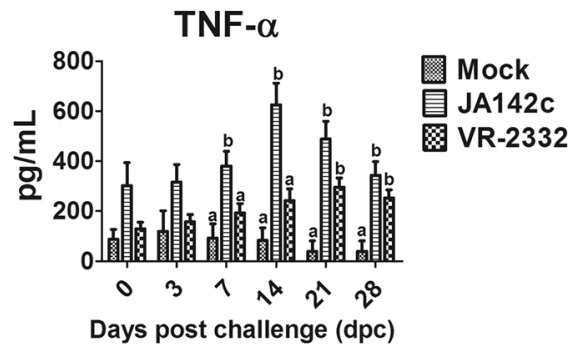

\section{IL-10}

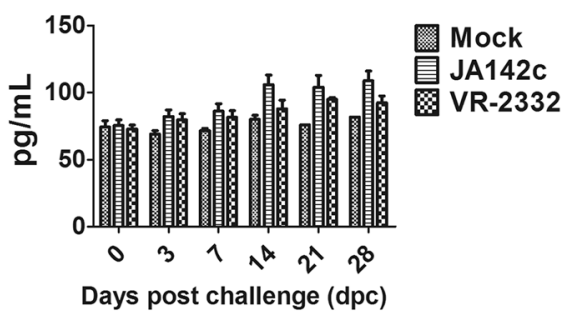

Fig. 5 Serum cytokine levels in PRRSV-infected pigs. Sera collected from pigs $(n=5)$ at $0,3,7,14,21$ and 28 dpc were analysed for a IFN-a; b TNF-a; c IL-12; d IL-10; and e IL-4 by ELISA. Each bar represents the average cytokine amount from 5 pigs \pm SEM. Bars showing different letters represent values that differ significantly from each other $(p<0.05)$

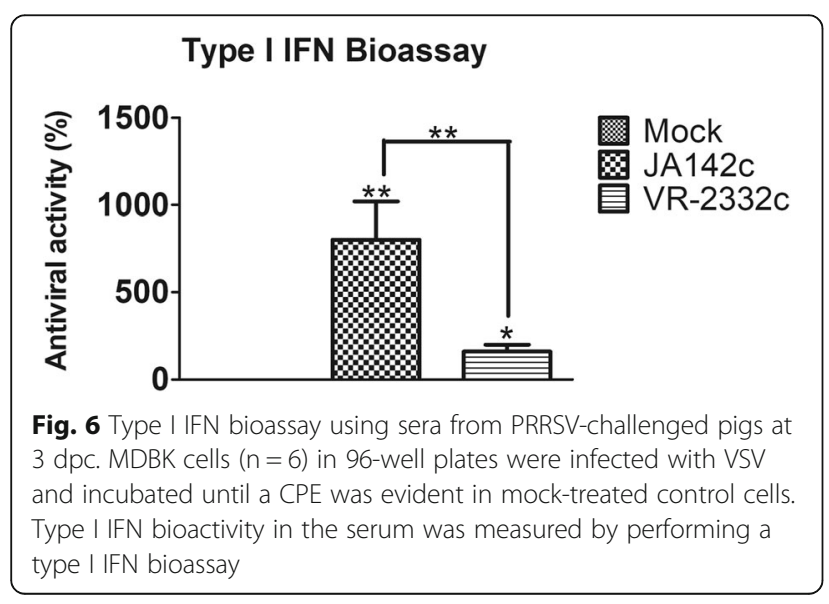

was also observed in PAMs and JA142c-challenged pigs at $7 \mathrm{dpc}$ than in VR2332c-challenged pigs, which is partially consistent with previous studies that demonstrated lower levels of IL-1 $\beta$, IL- 6 and IL-8 in VR2332c-challenged pigs $[44,51]$. Therefore, it was concluded that compared with VR2332c, JA142c consistently induced significantly higher levels of important pro-inflammatory cytokines in PAMs and pigs.

When $\mathrm{T}$ cell responses were analysed in pigs challenged with JA142c and VR2332c, compared with those from VR2332c- or mock-challenged pigs, PBMCs from JA142c-challenged pigs contained significantly larger populations of activated $\mathrm{CD} 4^{+} \mathrm{T}$ cells $\left(\mathrm{CD} 4^{+} \mathrm{CD} 25^{+}\right)$and exhibited significant and early increases in type I helper T cells $\left(\mathrm{CD} 4^{+} \mathrm{IFN}-\gamma^{+}\right)$and total IFN- $\gamma^{+}$cells. Cytotoxic T cells $\left(\mathrm{CD}^{+} \mathrm{IFN}^{-}{ }^{+}\right)$in both JA142c- and VR2332c -infected pigs increased at $14 \mathrm{dpc}$, but the JA142c group 
a

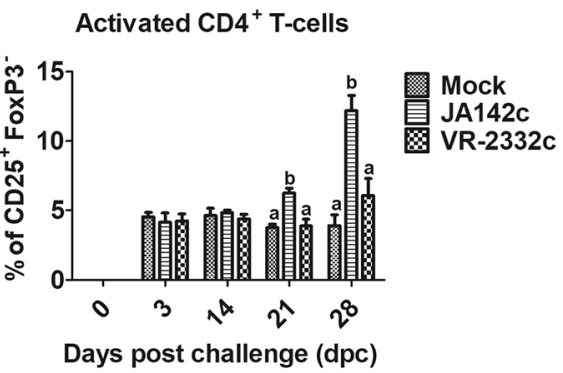

C

Cytotoxic T-cells

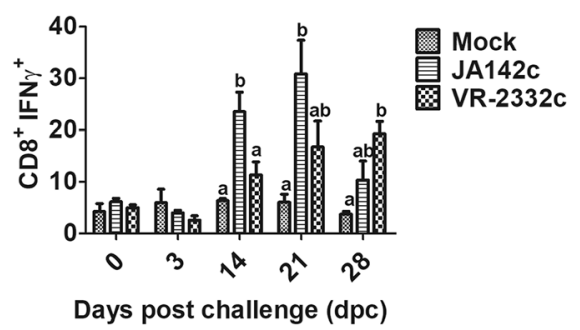

e

Regulatory T-cells

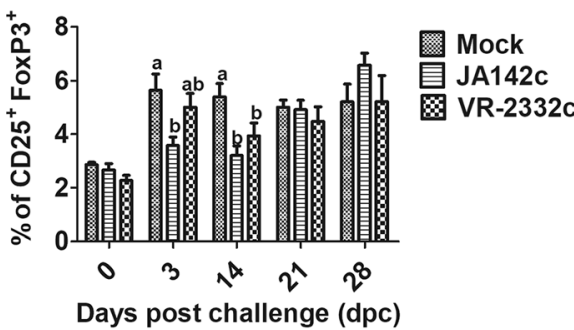

b

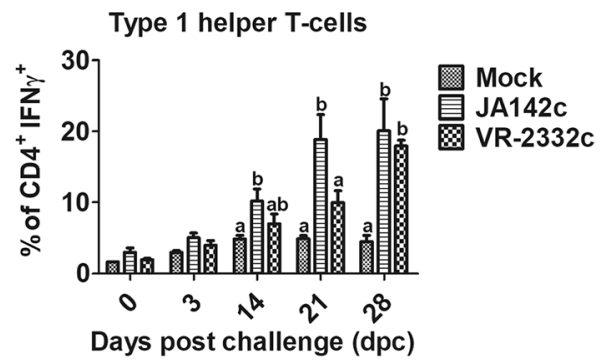

d

Total IFN $\gamma+$ Cells

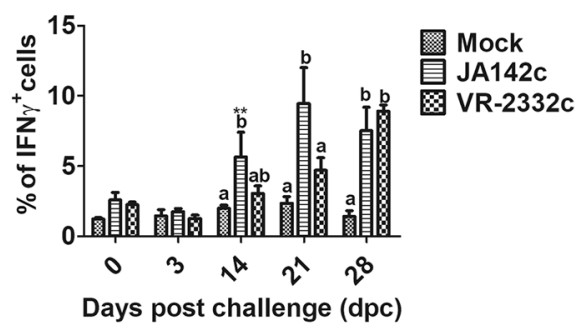

Fig. 7 Frequency of immune cells in PBMCs derived from PRRSV-infected pigs. a Activated $C D 4^{+} \mathrm{T}$ cells $\left(\mathrm{CD} 4^{+} \mathrm{CD} 25^{+}\right.$Foxp3 $\left.{ }^{-}\right)$, b type I helper T cells $\left(\mathrm{CD} 4^{+} \mathrm{IFN}-\gamma^{+}\right)$, c cytotoxic T cells $\left(\mathrm{CD} 8^{+} \mathrm{IFN}-\gamma^{+}\right)$, $\mathbf{d}$ total PBMCs expressing IFN- $\gamma^{+}$and $\mathbf{e} \mathrm{T}_{\text {Regs }}\left(\mathrm{CD} 4^{+} \mathrm{CD} 25^{+} \mathrm{Foxp} 3^{+}\right)$. Each bar represents the average percentage of immune cells from 5 pigs \pm SEM. Bars showing different letters represent values that differ significantly from each other $(p<0.05)$

had a significantly larger population of cytotoxic T lymphocytes (CTLs) than the mock- and VR2332c-infected groups. In a previous study, low numbers of PRRSV-specific IFN- $\gamma^{+} \mathrm{CD} 8^{+} \mathrm{T}$ cells were associated with a delayed CTL response [33].

\section{Conclusions}

Collectively, based on the results of the current study, JA142c induced more efficient innate and adaptive immune responses in vitro and in vivo than did VR2332c. Furthermore, of the two in vitro screening systems for immunogenicity (PAMs and PBMCs), PAMs generated immune response patterns to both PRRSVs that were similar to those elicited by these viruses in pigs. Thus, PAMs may be used as an immunogenicity screening tool for the selection of vaccine candidates against PRRSV. Finally, the induction of IFN- $\alpha$, TNF- $\alpha$ and IL-12 in PAMs might represent vital immune markers to predict the immunogenicity of PRRSV vaccine candidates in pigs.

\section{Methods}

Cells and viruses

MARC-145, an African green monkey kidney cell line that is highly permissive to PRRSV, was used for virus propagation and maintained in Roswell Park Memorial Institute (RPMI)-1640 medium (Gibco RPMI 1640, Life Technologies, Carlsbad, CA, USA) supplemented with heat-inactivated $10 \%$ fetal bovine serum (FBS, Life Technologies), $2 \mathrm{mM} \mathrm{L-glutamine,} \mathrm{and} \mathrm{100X} \mathrm{Antibiotic}$ -Antimycotic (Anti-anti, Life Technologies) containing $100 \mathrm{IU} / \mathrm{mL}$ penicillin, $100 \mu \mathrm{g} / \mathrm{mL}$ streptomycin, and $0.25 \mu \mathrm{g} / \mathrm{mL}$ Fungizone ${ }^{\circ}$ (amphotericin $\mathrm{B}$ ) in a $5 \% \mathrm{CO}_{2}$ humidified chamber at $37{ }^{\circ} \mathrm{C}$. In this study, this medium is referred to as complete RPMI (cRPMI) medium. Two 


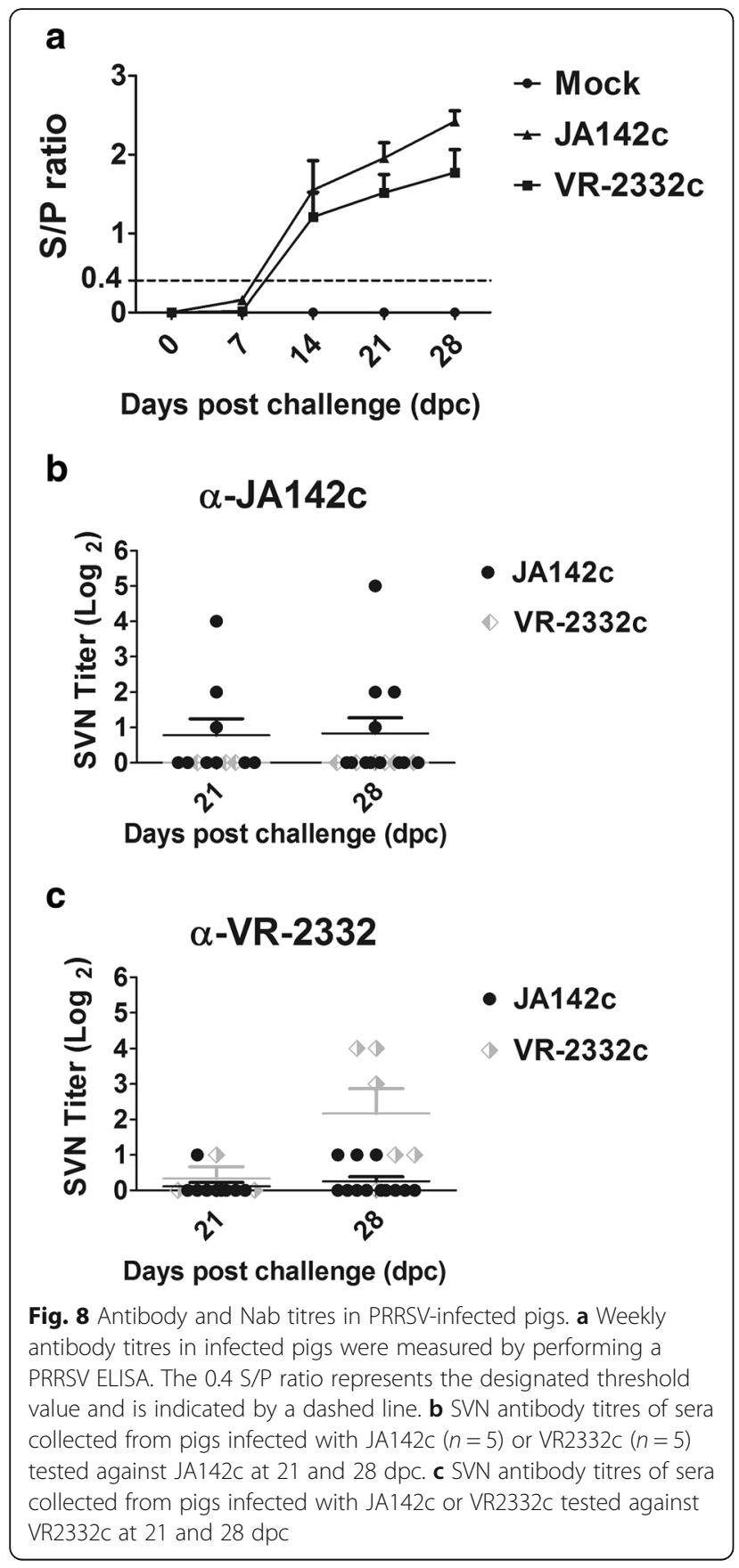

infectious clones of Type II PRRSV strains, JA142 and VR2332 [52, 53], were re-cloned into a vector (pOpti$\mathrm{VEC}^{\mathrm{m}}$-TOPO ${ }^{\circ}$ TA Cloning Kit, Life Technologies) to construct modified infectious clones by inserting viral sequences between the human cytomegalovirus (CMV) promoter and the internal ribosomal entry site (IRES) that are present in the vector $[54,55]$. The viruses rescued from each of the modified infectious clones were named JA142c and VR2332c. The infectious clone-driven viruses were used in this study to minimize mutations caused by passaging the virus in cells. a

Residual virus load in Lungs

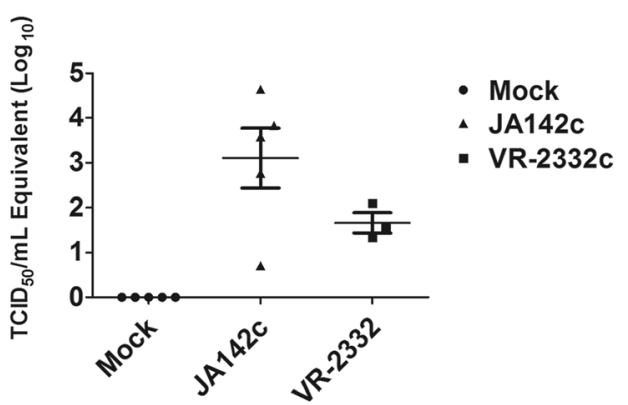

b

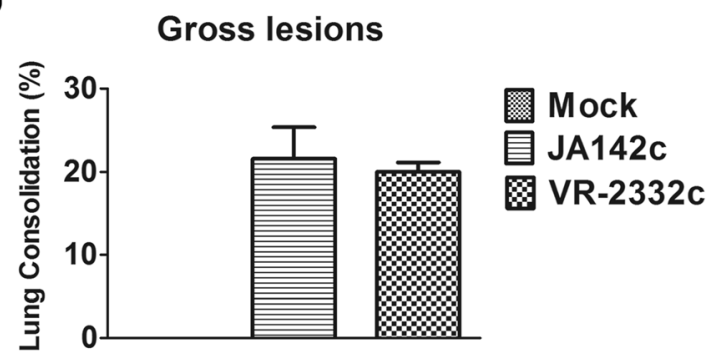

\section{Microscopic lesions}

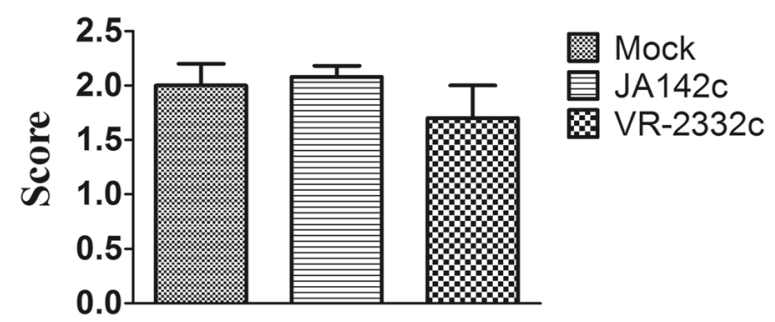

Fig. 9 Quantification of residual viral loads in the lungs and evaluation of gross and microscopic lung lesions at $28 \mathrm{dpc}$. a Residual viral loads in the lungs of PRRSV-infected pigs at $28 \mathrm{dpc}$. Viral titres were calculated based on the standard curve of the cycle threshold $(\mathrm{Ct})$ number plotted against the known viral titre of VR2332c. b Gross and c microscopic lung scores were recorded after necropsy. Lung scores were plotted as the mean values of the lesion scores from 5 pigs in each group, and the error bars represent the SEM

Harvesting porcine alveolar macrophages (PAMs) and collecting peripheral blood mononuclear cells (PBMCs) PAMs were harvested from six 6-week-old PRRSV -negative pigs, as described previously [56]. The pigs were euthanized, and the lungs, trachea and bronchus were aseptically collected. The lungs were lavaged three times with $50 \mathrm{~mL}$ of phosphate-buffered saline (PBS, $\mathrm{pH}$ 7.4), and the harvested wash fluid was centrifuged for $10 \mathrm{~min}$ at $1000 \mathrm{~g}$. The resulting pellet was washed three times with PBS and re-suspended in $5 \mathrm{~mL}$ of sterile PBS. To evaluate cell number and viability, the cells were diluted 100 -fold in PBS, mixed with $0.4 \%$ trypan 
blue at a 1:1 ratio and counted using a Countess ${ }^{\mathrm{TM}}$ Automated Cell Counter (Invitrogen, Carlsbad, CA, USA). After counting, freezing medium (70\% Dulbecco's modified Eagle's medium (DMEM) with high glucose, pyruvate, 20\% FBS [Gibco, California, USA], and 10\% dimethyl sulfoxide [Sigma-Aldrich, St. Louis, Missouri, USA]) was added to the cells to maintain the final cell density at $5 \times 10^{7}$ cells $/ \mathrm{mL}$. The cells were collected in cryovials and stored at $-80{ }^{\circ} \mathrm{C}$ until use.

PBMCs were isolated from 6-mL blood samples collected from six-week-old PRRSV-free pigs in lithium-heparin-containing vacutainers using a density gradient method in Histopaque- $1077^{\circ}$ solution (Sigma, St. Louis, MO, USA) according to the manufacturer's instructions. The blood samples were briefly stratified in Histopaque- $1077^{\circ}$ solution at a ratio of 1:1 (blood:Histopaque) and were centrifuged at $400 \mathrm{~g}$ for $30 \mathrm{~min}$. Purified PBMCs were collected, washed twice with sterile PBS (pH 7.0) supplemented with 1\% FBS (Gibco, Carlsbad, CA, USA) and re-suspended in $0.5 \mathrm{~mL}$ of sterile PBS.

\section{In vitro evaluation of the growth kinetics of JA142c and VR2332c}

The growth of JA142c and VR2332c was evaluated in MARC-145 cells. Confluent monolayers of MARC-145 cells were prepared in nine $25 \mathrm{~cm}^{2}$ flasks, with three flasks inoculated with each virus or mock inoculated at a multiplicity of infection (MOI) of 0.01 and incubated for $1 \mathrm{~h}$ in a humidified chamber at $37^{\circ} \mathrm{C}$. After incubation, the cells were replenished with cRPMI and incubated for an additional $48 \mathrm{~h}$. Supernatants were collected from each flask at $6,12,24,36$ and $48 \mathrm{~h}$, and the virus in these supernatants was titrated as described previously [57].

\section{Animal study}

A total of 15 three-week-old PRRSV-free pigs were purchased from a farm which has been PRRS-negative over last 10 years and randomly divided into 3 groups and housed separately in the animal research facility in Chonbuk National University. Five pigs in each group were challenged with VR2332c or JA142c diluted in RPMI to $10^{3} \mathrm{TCID}_{50} / \mathrm{mL}$ in a volume of $2 \mathrm{~mL}$ or with mock inoculum (sterile PBS) injected intramuscularly and housed for 4 weeks. All pigs were bled at $0,3,7,14$, 21 and 28 days post-challenge (dpc), and whole blood was collected for PBMC isolation to evaluate cytokine mRNA transcript levels and perform flow cytometry. Sera were separated immediately after bleeding and stored at $-80{ }^{\circ} \mathrm{C}$ until use. Viremia and serum cytokine levels in all pigs were evaluated weekly, at which point all pigs were weighed. Serum virus neutralizing antibody induction was evaluated at 21 and $28 \mathrm{dpc}$. All pigs were humanly euthanized at $28 \mathrm{dpc}$ by electrocution after intramuscular injection of $3 \mathrm{ml}$ of Azaperone $(40 \mathrm{mg} / \mathrm{ml}$,
StressGuar ${ }^{\oplus}$, Dong Bang Inc., Seoul, South Korea) for sedation and subjected to pathological evaluation. To evaluate gross and microscopic lung lesions, each lung lobe was scored for the percentage of lung consolidation [58] and interstitial pneumonia resulting from PRRSV infection. Scoring of microscopic lung lesions was recorded as follows: 0 indicates no lesion; 1 indicates mild interstitial pneumonia; 2 indicates moderate multifocal interstitial pneumonia; 3 indicates moderate diffuse interstitial pneumonia; and 4 indicates severe interstitial pneumonia. Lung tissues were collected from each pig and stored at $-80{ }^{\circ} \mathrm{C}$ until examination.

\section{Transcriptional activation of cellular cytokines}

PAMs re-suspended in cRPMI at $5 \times 10^{6}$ cells $/ \mathrm{mL}$ were seeded in each well of a 24-well plate (BD Falcon, Franklin Lakes, NJ, USA) and cultured overnight in a $5 \% \mathrm{CO}_{2}$ humidified chamber at $37{ }^{\circ} \mathrm{C}$. The cultured PAMs were stimulated with a $0.1 \mathrm{MOI}$ of either JA142c or VR2332c, $10 \mu \mathrm{g} / \mathrm{mL}$ polyinosinic-polycytidylic acid (poly $\mathrm{I}: \mathrm{C}$ ) (Sigma-Aldrich, St. Louis, MO, USA) or mock inoculum (cRPMI) and incubated in a $5 \% \mathrm{CO}_{2}$ humidified chamber at $37{ }^{\circ} \mathrm{C}$. Six PAMs harvested from six PRRSV-free pigs were used in the experiment. The cells were harvested, and the cell lysates were collected at 12, 24 and 36 hpi. Similarly, $1 \times 10^{6}$ naive PBMCs re-suspended in cRPMI were seeded in each well of a 24-well plate. The cells were stimulated with a $0.1 \mathrm{MOI}$ of either JA142c or VR2332c, $10 \mu \mathrm{g} / \mathrm{mL}$ poly I:C or mock inoculum (cRPMI) and incubated in a $5 \% \mathrm{CO}_{2}$ humidified chamber at $37{ }^{\circ} \mathrm{C}$, after which the cells were harvested, and the cell supernatants were collected at 12, 36 and 72 hpi. Four PBMC cells from 4 PRRSV-free pigs were used for the experiment. Poly I:C, a synthetic analogue of double-stranded RNA, was used as an immune-inducing positive control for PAMs and PBMCs. Cellular RNA was extracted using an RNA isolation kit (GeneAll ${ }^{\odot}$ Hybrid-RTM kit, GeneAll Biotechnology, Seoul, South Korea) following the manufacturer's instructions. RNA was analysed on agarose gels as initial quality checks and 260/280 and 260/230 ratios were determined to be 1.8-2.2 and 1.7 or higher, respectively. Then, $1 \mu \mathrm{g}$ of RNA was used for complementary DNA (cDNA) synthesis using a high-capacity cDNA reverse transcription kit (Applied Biosystems, Foster City, CA, USA) following the manufacturer's instructions. Real-time PCR was then performed on a 7500 Fast Real-time PCR system (Applied Biosystems) using various cytokine-specific primers, following the manufacturer's instructions. The primer sequences used in this study are shown in Table 1. Ten microlitres of 2X Power SYBR Green PCR Master Mix (Applied Biosystems, Foster City, CA, USA), $2 \mu \mathrm{L}$ of cDNA and $1 \mu \mathrm{L}$ of each forward and reverse primer (each at $10 \mathrm{pm} / \mu \mathrm{L}$ ) were used for PCR amplification. All samples were tested in duplicate, and the following 
Table 1 Information about the real-time PCR primers used to measure mRNA transcript levels of various cytokines

\begin{tabular}{|c|c|c|c|}
\hline Genes & Forward Primer (5'- 3') & Reverse Primer (5'- 3') & Accession/Reference \\
\hline$\beta$-Actin & GCGGGACATCAAGGAGAAG & AGGAAGGAGGGCTGGAAGAG & U07786 \\
\hline IFN-a & TCTCATGCACCAGAGCCA & CCTGGACCACAGAAGGGA & [39] \\
\hline IFN- $\beta$ & AGTGCATCCTCCAAATCGCT & GCTCATGGAAAGAGCTGTGGT & M86762 \\
\hline TNF-a & TTATTCAGGAGGGCGAGGT & AGCAAAAGGAGGCACAGAGG & NM214022 \\
\hline IL-1a & GTGCTCAAAACGAAGACGAACC & CATATTGCCATGCTITTCCCAGAA & NM_214029.1 \\
\hline$I L-1 \beta$ & AACGTGCAGTCTATGGAGT & GAACACCACTTCTCTCTTCA & M86725 \\
\hline IL-6 & CCACCAGGAACGAAAGAGAG & AGGCAGTAGCCATCACCAGA & NM_214399 \\
\hline IL-8 & TAGGACCAGAGCCAGGAAGA & CAGGAAAACTGCCAAGAAGG & M86923.1 \\
\hline IL-10 & TGACGATGAAGATGAGGAAGAA & GAACCTTGGAGCAGATTTGA & NM214041 \\
\hline $\mathrm{IL}-12$ & TCAGGGACATCATCAAACCA & GAACACCAAACATCAGGGAAA & NM214013 \\
\hline $\mathrm{IFN}-\gamma$ & GACTITGTGTITTCTGGCTCTTAC & TITTGTCACTCTCCTCTITCCA & NM213948 \\
\hline $\mathrm{IL}-2$ & TGCACTAACCCTTGCACTCA & CCTGCTTGGGCATGTAAAAT & $\times 56750$ \\
\hline IL-4 & TाTGCTGCCCCAGAGAAC & TCCTGTCAAGTCCGCTCA & X68330 \\
\hline
\end{tabular}

IL interleukin, IFN interferon

cycling conditions were applied: (a) incubation for $10 \mathrm{~min}$ at $95^{\circ} \mathrm{C}$; (b) 40 cycles of $15 \mathrm{~s}$ at $95^{\circ} \mathrm{C}$ and $1 \mathrm{~min}$ at $60{ }^{\circ} \mathrm{C}$; and (c) a melting curve stage of $15 \mathrm{~s}$ at $95{ }^{\circ} \mathrm{C}, 1 \mathrm{~min}$ at $60{ }^{\circ} \mathrm{C}, 15 \mathrm{~s}$ at $95^{\circ} \mathrm{C}$ and $15 \mathrm{~s}$ at $60{ }^{\circ} \mathrm{C}$. The relative quantities of cytokine mRNA in infected and non-infected cells were normalized to $\beta$-actin mRNA, and the amounts were determined using the $2^{-\Delta \Delta C t}$ method [59].

\section{Cytokine quantification by ELISA}

Commercially available porcine-specific ELISA kits were used to quantify various cytokine protein levels in sera, cell supernatants or lysates, including TNF- $\alpha$, IL-4, IL-10, and IL-12 (DuoSet ${ }^{\ominus}$ ELISA, R\&D Systems, MN, USA), according to the manufacturer's instructions.

To detect IFN- $\alpha$ protein levels in sera and cell lysates, $100 \mu \mathrm{L}(1.8 \mu \mathrm{g} / \mathrm{mL})$ of a mouse anti-pig IFN- $\alpha$ antibody (Clone F17, PBL Assay Science, NJ, USA) was used as a coating antibody, and a mouse anti-pig IFN- $\alpha$ antibody (Clone K9, PBL Assay Science, NJ, USA) was biotinylated and used as a secondary antibody, with recombinant porcine IFN- $\alpha$ (PBL Assay Science, NJ, USA) as a standard. The procedure was carried out using the provided ELISA reagents (eBioscience, CA, USA) and following the manufacturer's instructions. The results were analysed using SoftMax Pro 5.3 microplate data software (Molecular Devices, CA, USA).

\section{Type I IFN bioassay}

A conventional type I IFN bioassay using sera from virus-challenged pigs was performed to assess the amount of virus-induced type I IFNs present by determining anti-vesicular stomatitis virus (VSV) activity. MDBK cells were seeded in 96-well cell culture plates (BD Falcon, Franklin Lakes, NJ, USA) $\left(5 \times 10^{5}\right.$ cells/well $)$ and incubated for $20 \mathrm{~h}$ in the presence of two-fold dilutions of recombinant IFN- $\alpha$ ( $r-I F N-\alpha)$ (PBL Assay Science, NJ, USA), as described previously. The cells were infected with propagation-competent VSV (0.01 MOI) and incubated until a cytopathic effect (CPE) was evident in mock-treated control cells. The cells were washed twice with PBS and stained for $1 \mathrm{~h}$ with $0.1 \%$ crystal violet in $10 \%$ formalin. The plates were then washed with tap water to remove excess crystal violet and dried. The dye was dissolved by adding $100 \mathrm{~mL}$ of $70 \%$ ethanol to each well. Crystal violet absorbance at $595 \mathrm{~nm}$ was determined with a microplate reader. Antiviral activity was calculated as described previously [54].

\section{Quantification of PRRSV RNA in sera and lungs}

Viral RNA was extracted from $100 \mu \mathrm{L}$ of serum and $1 \mathrm{~g}$ of lung samples using a viral RNA extraction kit (MagMAX $^{\mathrm{sm}}$ Viral RNA Isolation Kit, Life Technologies) and a total RNA extraction kit (Hybrid-RTM, GeneAll, Seoul, Korea) according to the manufacturer's instructions. The viral loads in sera and lungs were measured by performing real-time RT-PCR employing a one-step reverse transcriptase kit (AgPath-IDTM One-Step RT-PCR Kit, Ambion, Austin, TX, USA) with a 7500 Fast Real-time PCR system (Applied Biosystems, Foster City, CA, USA), although this test cannot differentiate between replication-competent and replication-incompetent virus. Primers and a minor groove binder (MGB) fluorescent probe specific to a conserved region of ORF7 were employed as described previously [60].

\section{Assessment of PRRSV-specific antibodies}

A fluorescence focus neutralization (FFN)-based serum virus neutralization (SVN) assay was performed to evaluate NAb titres induced by PRRSVs after challenge. The 
SVN assay was performed in MARC-145 cells as described previously $[61,62]$. The NAb titres of each anti-serum against each virus were expressed as the reciprocal of the highest dilution for which a $90 \%$ or greater reduction in the number of fluorescent focus units (FFU)/mL was observed compared to the wells for each respective virus back-titration.

The presence of PRRSV nucleocapsid-specific antibodies in the sera of infected animals was determined using a direct ELISA kit (HerdCheck ${ }^{\circ}$ PRRS Antibody Kit 3XR, IDEXX Laboratories, Westbrook, ME, USA) according to the manufacturer's instructions.

\section{Flow cytometry}

The frequency and phenotype of the immune cell populations were determined by performing multicolour immunostaining of single-cell suspensions on the day of PBMC isolation. PBMCs were evaluated for the expression of markers of activated $\mathrm{CD} 4^{+} \mathrm{T}$ cells $\left(\mathrm{CD} 4^{+} \mathrm{CD} 25^{+} \mathrm{FoxP} 3^{-}\right)$, regulatory $\mathrm{T}$ cells $\left(\mathrm{CD} 4^{+} \mathrm{CD} 25^{+} \mathrm{FoxP}^{+}\right)$, type I helper $\mathrm{T}$ cells $\left(\mathrm{CD} 4^{+} \mathrm{IFN}-\gamma^{+}\right)$, and cytotoxic T cells $\left(\mathrm{CD} 8^{+} \mathrm{IFN}-\gamma^{+}\right)$. The cells were stained with an appropriate monoclonal antibody (mAb), which was either directly conjugated to a specific fluorochrome or biotinylated, or with a purified antibody targeting porcine-specific immune cell surface markers as described previously [63]. Briefly, $1 \times 10^{6}$ purified PBMCs per sample were re-suspended in fluorescence-activated cell sorting (FACS) buffer (2\% FBS in PBS with $0.02 \%$ sodium azide), and two replicates of each sample were plated in two separate U-bottom 96-well plates with $1 \times 10^{6}$ cells per well in a $200-\mu \mathrm{L}$ volume. Subsequently, the cells in one plate were stained with either CD4 $\alpha-\mathrm{PE}$ (Clone 74-12-4; BD Biosciences, Franklin Lakes, New Jersey, USA) or anti-porcine CD25 (clone K231.3B3; Serotech, Raleigh, NC), followed by washing and staining with an allophycocyanin-conjugated rat anti-mouse IgG1 antibody (Ab) (Clone RMG1-1; Biolegend, San Diego, CA, USA) as a secondary antibody against anti-CD25 according to the manufacturer's instructions. Afterwards, the cells were fixed and stained with a FoxP3-FITC antibody (Clone FJK-16 s; eBiosciences, San Diego, CA, USA), as described. Simultaneously, two other sets of cells were treated with a $1 \mathrm{X}$ cell stimulation cocktail (eBiosciences) plus 1X brefeldin A (eBiosciences) in cRPMI media and incubated at $37^{\circ} \mathrm{C}$ in a $5 \% \mathrm{CO}_{2}$ humidified chamber for $5 \mathrm{~h}$. Afterwards, one set of cells was stained with CD8 $\alpha$-FITC (Clone 76-2-11; $\mathrm{BD}$ Biosciences), and the other set of cells was stained with CD4 $\alpha-\mathrm{PE}$ and fixed with IC fixation buffer (eBiosciences) according to the manufacturer's instructions. Finally, the cells were stained with IFN- $\gamma$-PerCP-Cy ${ }^{\text {rm }} 5.5$ (Clone P2G10; BD Biosciences). A total of 100,000 events (gated by forward and side scatter) were acquired for each sample using an Accuri C6 flow cytometer (BD
Biosciences, Franklin Lakes, New Jersey, USA), and the data were analysed using BD CFlow'Plus software v. 1.0.227.4 (BD Biosciences, Franklin Lakes, New Jersey, USA). Target cell frequencies were expressed as the percentage for a specific cell subset.

\section{Data analysis}

Graphs were constructed using GraphPad Prism 5.0.2 (GraphPad, San Diego, CA, USA), and statistical analyses were performed using SPSS Advanced Statistics 17.0 software (SPSS, Inc., Chicago, USA). The Mann-Whitney $U$ test was applied to estimate differences between different groups. Repeated measurements of viremia and PRRSV nucleocapsid-specific antibody levels in challenged pigs were analysed using a repeated ANOVA test (Tukey's post hoc test) to determine the overall difference, and pairwise comparisons were also made between groups.

\section{Abbreviations \\ CTLs: Cytotoxic T lymphocytes; IFNs: Interferons; Nabs: Neutralizing antibodies; NSPs: Non-structural proteins; PAMs: Porcine alveolar macrophages; PBMCs: Peripheral blood mononuclear cells; PRRS: Porcine reproductive and respiratory syndrome; $T_{\text {Regs }}$ : Regulatory $T$ cells}

\section{Acknowledgements}

The authors wish to acknowledge the assistance of the lab technicians and undergraduate students from the College of Veterinary Medicine, Veterinary Diagnostic Center, Chonbuk National University.

\section{Funding}

The authors wish to acknowledge the assistance of the lab technicians and undergraduate students from the College of Veterinary Medicine, Veterinary Diagnostic Center, Chonbuk National University. This study was supported by grants from the Technology Development Program for Bio-industry (315029-3) and the Cooperative Research Program for Agriculture Science \& Technology Development (PJ012612) in Rural Development Administration, Ministry of Agriculture, Food and Rural Affairs, Republic of Korea.

\section{Availability of data and materials}

All data generated or analysed during the study are included in this published article. The datasets used and/or analysed during the present research project are available from the corresponding author on reasonable request.

\section{Authors' contributions}

NS and AK performed the experiments and drafted the manuscript; SN and SG helped with the animal experimentation and the ELISA and type-1 IFN bioassay experiments; SML and TYH provided vital input; MSY and BSK evaluated the lungs for lesions; and WK designed the entire study and assisted in drafting the manuscript. All authors read and approved the final manuscript.

\section{Ethics approval and consent to participate}

The animal experiment protocol was approved by the Chonbuk National University Institutional Animal Care and Use Committee (Approval Number: 2012-0025) and performed in accordance with the guidelines and regulations of the committee.

\section{Consent for publication}

Not applicable.

\section{Competing interests}

The authors declare that they have no competing interests.

\section{Publisher's Note}

Springer Nature remains neutral with regard to jurisdictional claims in published maps and institutional affiliations. 


\section{Author details}

${ }^{1}$ College of Veterinary Medicine, Chonbuk National University, 79 Gobong-ro, Iksan, Jeonbuk, Korea. ${ }^{2}$ Division of Animal Biotechnology, Faculty of Veterinary Sciences and Animal Husbandry, Sher-e-Kashmir University of Agricultural Sciences and Technology of Kashmir, Srinagar, India. ${ }^{3}$ College of Environmental \& Biosource Science, Division of Biotechnology, Chonbuk National University, Iksan, South Korea. ${ }^{4}$ Dairy Science Division, National Institute of Animal Science, Rural Development Administration, Cheonan 31000, South Korea.

Received: 26 March 2018 Accepted: 29 October 2018 Published online: 04 December 2018

\section{References}

1. Cavanagh D. Nidovirales: a new order comprising Coronaviridae and Arteriviridae. Arch Virol. 1997;142(3):629-33.

2. Collins JE, Benfield DA, Christianson WT, Harris L, Hennings JC, Shaw DP, Goyal SM, McCullough S, Morrison RB, Joo HS, et al. Isolation of swine infertility and respiratory syndrome virus (isolate ATCC VR-2332) in North America and experimental reproduction of the disease in gnotobiotic pigs. J Vet Diagn Investig. 1992:4(2):117-26.

3. Wensvoort G, Terpstra C, Pol JM, ter Laak EA, Bloemraad M, de Kluyver EP, Kragten C, van Buiten L, den Besten A, Wagenaar F, et al. Mystery swine disease in the Netherlands: the isolation of Lelystad virus. Vet Q. 1991;13(3):121-30.

4. Holtkamp DJ, Kliebenstein JB, Neumann E, Zimmerman JJ, Rotto H, Yoder TK, Wang C, Yeske P, Mowrer CL, Haley CA. Assessment of the economic impact of porcine reproductive and respiratory syndrome virus on United States pork producers. J Swine Health Prod. 2013;21(2):72.

5. Firth $A E$, Zevenhoven-Dobbe JC, Wills NM, Go YY, Balasuriya UB, Atkins JF, Snijder EJ, Posthuma CC. Discovery of a small arterivirus gene that overlaps the GP5 coding sequence and is important for virus production. J Gen Virol. 2011;92(Pt 5):1097-106.

6. Johnson CR, Griggs TF, Gnanandarajah J, Murtaugh MP. Novel structural protein in porcine reproductive and respiratory syndrome virus encoded by an alternative ORF5 present in all arteriviruses. J Gen Virol. 2011;92:1107-16.

7. Shi M, Lam TT, Hon CC, Hui RK, Faaberg KS, Wennblom T, Murtaugh MP, Stadejek T, Leung FC. Molecular epidemiology of PRRSV: a phylogenetic perspective. Virus Res. 2010;154(1-2):7-17.

8. Shi M, Lam TT, Hon CC, Murtaugh MP, Davies PR, Hui RK, Li J, Wong LT, Yip CW, Jiang JW, et al. Phylogeny-based evolutionary, demographical, and geographical dissection of North American type 2 porcine reproductive and respiratory syndrome viruses. J Virol. 2010;84(17):8700-11.

9. Gimeno M, Darwich L, Diaz I, de la Torre E, Pujols J, Martin M, Inumaru S, Cano $\mathrm{E}$, Domingo M, Montoya $\mathrm{M}$, et al. Cytokine profiles and phenotype regulation of antigen presenting cells by genotype-I porcine reproductive and respiratory syndrome virus isolates. Vet Res. 2011:42:9.

10. Silva-Campa E, Cordoba L, Fraile L, Flores-Mendoza L, Montoya M, Hernandez J. European genotype of porcine reproductive and respiratory syndrome (PRRSV) infects monocyte-derived dendritic cells but does not induce Treg cells. Virology. 2010;396(2):264-71.

11. Meng XJ. Heterogeneity of porcine reproductive and respiratory syndrome virus: implications for current vaccine efficacy and future vaccine development. Vet Microbiol. 2000;74(4):309-29.

12. $\mathrm{Vu} \mathrm{HL}$, Pattnaik AK, Osorio FA. Strategies to broaden the cross-protective efficacy of vaccines against porcine reproductive and respiratory syndrome virus. Vet Microbiol. 2017:206:29-34

13. Park JY, Kim HS, Seo SH. Characterization of interaction between porcine reproductive and respiratory syndrome virus and porcine dendritic cells. J Microbiol Biotechnol. 2008;18(10):1709-16.

14. Song S, Bi J, Wang D, Fang L, Zhang L, Li F, Chen H, Xiao S. Porcine reproductive and respiratory syndrome virus infection activates IL-10 production through NF-kappaB and p38 MAPK pathways in porcine alveolar macrophages. Dev Comp Immunol. 2013:39(3):265-72.

15. Wang G, Song T, Yu Y, Liu Y, Shi W, Wang S, Rong F, Dong J, Liu H, Cai X, et al. Immune responses in piglets infected with highly pathogenic porcine reproductive and respiratory syndrome virus. Vet Immunol Immunopathol. 2011:142(3-4):170-8.

16. Albina E, Carrat C, Charley B. Interferon-alpha response to swine arterivirus (PoAV), the porcine reproductive and respiratory syndrome virus. J Interferon Cytokine Res. 1998;18(7):485-90.
17. Buddaert W, Van Reeth K, Pensaert M. In vivo and in vitro interferon (IFN) studies with the porcine reproductive and respiratory syndrome virus (PRRSV). Adv Exp Med Biol. 1998:440:461-7.

18. Han M, Yoo D. Modulation of innate immune signaling by nonstructural protein 1 (nsp1) in the family Arteriviridae. Virus Res. 2014;194:100-9.

19. Gomez-Laguna J, Salquero FJ, Pallares FJ, Carrasco L. Immunopathogenesis of porcine reproductive and respiratory syndrome in the respiratory tract of pigs. Vet J. 2013;195(2):148-55.

20. Lopez-Fuertes L, Campos E, Domenech N, Ezquerra A, Castro JM, Dominguez J, Alonso F. Porcine reproductive and respiratory syndrome (PRRS) virus down-modulates TNF-alpha production in infected macrophages. Virus Res. 2000;69(1):41-6.

21. Baumann A, Mateu E, Murtaugh MP, Summerfield A. Impact of genotype 1 and 2 of porcine reproductive and respiratory syndrome viruses on interferonalpha responses by plasmacytoid dendritic cells. Vet Res. 2013:44:33.

22. Lee SM, Schommer SK, Kleiboeker SB. Porcine reproductive and respiratory syndrome virus field isolates differ in in vitro interferon phenotypes. Vet Immunol Immunopathol. 2004;102(3):217-31.

23. He Q, Li Y, Zhou L, Ge X, Guo X, Yang H. Both Nsp1beta and Nsp11 are responsible for differential TNF-alpha production induced by porcine reproductive and respiratory syndrome virus strains with different pathogenicity in vitro. Virus Res. 2015;201:32-40.

24. Diaz I, Darwich L, Pappaterra G, Pujols J, Mateu E. Different European-type vaccines against porcine reproductive and respiratory syndrome virus have different immunological properties and confer different protection to pigs. Virology. 2006;351(2):249-59

25. Aasted B, Bach P, Nielsen J, Lind P. Cytokine profiles in peripheral blood mononuclear cells and lymph node cells from piglets infected in utero with porcine reproductive and respiratory syndrome virus. Clin Diagn Lab Immunol. 2002:9(6):1229-34

26. Thanawongnuwech R, Young TF, Thacker BJ, Thacker EL. Differential production of proinflammatory cytokines: in vitro PRRSV and mycoplasma hyopneumoniae co-infection model. Vet Immunol Immunopathol. 2001; 79(1-2):115-27.

27. Liu CH, Chaung HC, Chang HL, Peng YT, Chung WB. Expression of toll-like receptor mRNA and cytokines in pigs infected with porcine reproductive and respiratory syndrome virus. Vet Microbiol. 2009;136(3-4):266-76.

28. Peng YT, Chaung HC, Chang HL, Chang HC, Chung WB. Modulations of phenotype and cytokine expression of porcine bone marrow-derived dendritic cells by porcine reproductive and respiratory syndrome virus. Vet Microbiol. 2009;136(3-4):359-65.

29. van Gucht S, van Reeth K, Pensaert M. Interaction between porcine reproductive-respiratory syndrome virus and bacterial endotoxin in the lungs of pigs: potentiation of cytokine production and respiratory disease. J Clin Microbiol. 2003;41(3):960-6.

30. Meier WA, Husmann RJ, Schnitzlein WM, Osorio FA, Lunney JK, Zuckermann FA. Cytokines and synthetic double-stranded RNA augment the T helper 1 immune response of swine to porcine reproductive and respiratory syndrome virus. Vet Immunol Immunopathol. 2004;102(3):299-314.

31. Xiao Z, Trincado CA, Murtaugh MP. Beta-glucan enhancement of T cell IFNgamma response in swine. Vet Immunol Immunopathol. 2004;102(3): 315-20.

32. Costers S, Lefebvre DJ, Goddeeris B, Delputte PL, Nauwynck HJ. Functional impairment of PRRSV-specific peripheral CD3+CD8high cells. Vet Res. 2009; 40(5):46.

33. Ferrari L, Martelli P, Saleri R, De Angelis E, Cavalli V, Bresaola M, Benetti M, Borghetti P. Lymphocyte activation as cytokine gene expression and secretion is related to the porcine reproductive and respiratory syndrome virus (PRRSV isolate after in vitro homologous and heterologous recall of peripheral blood mononuclear cells (PBMC) from pigs vaccinated and exposed to natural infection. Vet Immunol Immunopathol. 2013;151(3-4):193-206.

34. Silva-Campa E, Mata-Haro V, Mateu E, Hernandez J. Porcine reproductive and respiratory syndrome virus induces CD4+CD8+CD25+Foxp3+ regulatory T cells (Tregs). Virology. 2012;430(1):73-80.

35. Rodriguez-Gomez IM, Kaser T, Gomez-Laguna J, Lamp B, Sinn L, Rumenap T, Carrasco L, Saalmuller A, Gerner W. PRRSV-infected monocyte-derived dendritic cells express high levels of SLA-DR and CD80/86 but do not stimulate PRRSV-naive regulatory T cells to proliferate. Vet Res. 2015:46:54

36. Darwich L, Diaz I, Mateu E. Certainties, doubts and hypotheses in porcine reproductive and respiratory syndrome virus immunobiology. Virus Res. 2010;154(1-2):123-32 
37. Kimman TG, Cornelissen LA, Moormann RJ, Rebel JM, Stockhofe-Zurwieden $\mathrm{N}$. Challenges for porcine reproductive and respiratory syndrome virus (PRRSV) vaccinology. Vaccine. 2009;27(28):3704-18.

38. Mateu E, Diaz I. The challenge of PRRS immunology. Vet J. 2008;177(3):345-51.

39. Loving CL, Osorio FA, Murtaugh MP, Zuckermann FA. Innate and adaptive immunity against porcine reproductive and respiratory syndrome virus. Vet Immunol Immunopathol. 2015;167(1-2):1-14.

40. Plagemann PG. Neutralizing antibody formation in swine infected with seven strains of porcine reproductive and respiratory syndrome virus as measured by indirect ELISA with peptides containing the GP5 neutralization epitope. Viral Immunol. 2006;19(2):285-93.

41. Kim WI, Lee DS, Johnson W, Roof M, Cha SH, Yoon KJ. Effect of genotypic and biotypic differences among PRRS viruses on the serologic assessment of pigs for virus infection. Vet Microbiol. 2007;123(1-3):1-14.

42. Brockmeier SL, Loving CL, Nelson EA, Miller LC, Nicholson TL, Register KB, Grubman MJ, Brough DE, Kehrli ME Jr. The presence of alpha interferon at the time of infection alters the innate and adaptive immune responses to porcine reproductive and respiratory syndrome virus. Clin Vaccine Immunol. 2012;19(4):508-14.

43. Royaee AR, Husmann RJ, Dawson HD, Calzada-Nova G, Schnitzlein WM, Zuckermann FA, Lunney JK. Deciphering the involvement of innate immune factors in the development of the host response to PRRSV vaccination. Vet Immunol Immunopathol. 2004;102(3):199-216.

44. Guo B, Lager KM, Henningson JN, Miller LC, Schlink SN, Kappes MA, Kehrli ME Jr, Brockmeier SL, Nicholson TL, Yang HC, et al. Experimental infection of United States swine with a Chinese highly pathogenic strain of porcine reproductive and respiratory syndrome virus. Virology. 2013;435(2):372-84.

45. Gudmundsdottir I, Risatti GR. Infection of porcine alveolar macrophages with recombinant chimeric porcine reproductive and respiratory syndrome virus: effects on cellular gene transcription and virus growth. Virus Res. 2009; 145(1):145-50

46. Badaoui B, Rutigliano T, Anselmo A, Vanhee M, Nauwynck H, Giuffra E, Botti S. RNA-sequence analysis of primary alveolar macrophages after in vitro infection with porcine reproductive and respiratory syndrome virus strains of differing virulence. PLoS One. 2014;9(3):e91918.

47. Overend CC, Cui J, Grubman MJ, Garmendia AE. The activation of the IFNbeta induction/signaling pathway in porcine alveolar macrophages by porcine reproductive and respiratory syndrome virus is variable. Vet Res Commun. 2017:41(1):15-22.

48. Huang C, Zhang Q, Feng WH. Regulation and evasion of antiviral immune responses by porcine reproductive and respiratory syndrome virus. Virus Res. 2015;202:101-11.

49. Ait-Ali T, Wilson AD, Westcott DG, Clapperton M, Waterfall M, Mellencamp MA, Drew TW, Bishop SC, Archibald AL. Innate immune responses to replication of porcine reproductive and respiratory syndrome virus in isolated swine alveolar macrophages. Viral Immunol. 2007;20(1):105-18.

50. Choi C, Cho WS, Kim B, Chae C. Expression of interferon-gamma and tumour necrosis factor-alpha in pigs experimentally infected with porcine reproductive and respiratory syndrome virus (PRRSV). J Comp Pathol. 2002; 127(2-3):106-13.

51. Manickam C, Dwivedi V, Patterson R, Papenfuss T, Renukaradhya GJ. Porcine reproductive and respiratory syndrome virus induces pronounced immune modulatory responses at mucosal tissues in the parental vaccine strain VR2332 infected pigs. Vet Microbiol. 2013;162(1):68-77.

52. Truong HM, Lu Z, Kutish GF, Galeota J, Osorio FA, Pattnaik AK. A highly pathogenic porcine reproductive and respiratory syndrome virus generated from an infectious CDNA clone retains the in vivo virulence and transmissibility properties of the parental virus. Virology. 2004;325(2):308-19.

53. Nielsen HS, Liu G, Nielsen J, Oleksiewicz MB, Botner A, Storgaard T, Faaberg KS. Generation of an infectious clone of VR-2332, a highly virulent North American-type isolate of porcine reproductive and respiratory syndrome virus. J Virol. 2003;77(6):3702-11.

54. Berger Rentsch M, Zimmer G. A vesicular stomatitis virus replicon-based bioassay for the rapid and sensitive determination of multi-species type I interferon. PLoS One. 2011;6(10):e25858.

55. Sun D, Khatun A, Kim WI, Cooper V, Cho Yl, Wang C, Choi EJ, Yoon KJ. Attempts to enhance cross-protection against porcine reproductive and respiratory syndrome viruses using chimeric viruses containing structural genes from two antigenically distinct strains. Vaccine. 2016;34(36):4335-42.

56. OIE. Porcine reproductive and respiratory syndrome, Terrestrial Manual for Diagnostics and Vaccines, vol. Chapter 2.08.07; 2011.
57. Khatun A, Shabir N, Yoon KJ, Kim WI. Effects of ribavirin on the replication and genetic stability of porcine reproductive and respiratory syndrome virus. BMC Vet Res. 2015;11:21.

58. Halbur PG, Miller LD, Paul PS, Meng XJ, Huffman EL, Andrews JJ. Immunohistochemical identification of porcine reproductive and respiratory syndrome virus (PRRSV) antigen in the heart and lymphoid system of threeweek-old colostrum-deprived pigs. Vet Pathol. 1995;32(2):200-4.

59. Winer J, Jung CK, Shackel I, Williams PM. Development and validation of real-time quantitative reverse transcriptase-polymerase chain reaction for monitoring gene expression in cardiac myocytes in vitro. Anal Biochem. 1999;270(1):41-9.

60. Opriessnig T, McKeown NE, Harmon KL, Meng XJ, Halbur PG. Porcine circovirus type 2 infection decreases the efficacy of a modified live porcine reproductive and respiratory syndrome virus vaccine. Clin Vaccine Immunol. 2006;13(8):923-9.

61. Kim WI, Kim JJ, Cha SH, Yoon KJ. Different biological characteristics of wildtype porcine reproductive and respiratory syndrome viruses and vaccine viruses and identification of the corresponding genetic determinants. J Clin Microbiol. 2008;46(5):1758-68.

62. Wu WH, Fang Y, Farwell R, Steffen-Bien M, Rowland RR, Christopher-Hennings J, Nelson EA. A 10-kDa structural protein of porcine reproductive and respiratory syndrome virus encoded by ORF2b. Virology. 2001;287(1):183-91.

63. Niu P, Shabir N, Khatun A, Seo BJ, Gu S, Lee SM, Lim SK, Kim KS, Kim WI. Effect of polymorphisms in the GBP1, Mx1 and CD163 genes on host responses to PRRSV infection in pigs. Vet Microbiol. 2016;182:187-95.

\section{Ready to submit your research? Choose BMC and benefit from:}

- fast, convenient online submission

- thorough peer review by experienced researchers in your field

- rapid publication on acceptance

- support for research data, including large and complex data types

- gold Open Access which fosters wider collaboration and increased citations

- maximum visibility for your research: over $100 \mathrm{M}$ website views per year

At BMC, research is always in progress.

Learn more biomedcentral.com/submissions 